\title{
Spatial Distribution and Contamination Assessment of Surface Heavy Metals off the Western Guangdong Province and Northeastern Hainan Island
}

\author{
Qian Ge ${ }^{1,2, *}$, Zuo George Xue ${ }^{3,4,5}$ and Fengyou Chu ${ }^{1,2}$ \\ 1 Second Institute of Oceanography, State Oceanic Administration, Hangzhou 310012, China; chu@sio.org.cn \\ 2 Key Laboratory of Submarine Geosciences, State Oceanic Administration, Hangzhou 310012, China; \\ 3 Department of Oceanography and Coastal Sciences, Louisiana State University, Baton Rouge, LA 70803, \\ USA; zxue@lsu.edu \\ 4 Center for Computation and Technology, Louisiana State University, Baton Rouge, LA 70803, USA \\ 5 Coastal Studies Institute, Louisiana State University, Baton Rouge, LA 70803, USA \\ * Correspondence: gq980447@hotmail.com; Tel.: +86-571-81963169
}

Received: 29 July 2018; Accepted: 30 August 2018; Published: 31 August 2018

\begin{abstract}
Surface sediments collected from the continental shelf off the western Guangdong Province and northeastern Hainan Island are analyzed for selected heavy metals contents including $\mathrm{Cd}, \mathrm{Cr}, \mathrm{Cu}, \mathrm{Pb}$, $\mathrm{Zn}$, and As to determine spatial distribution, potential ecological risks, and sources. In addition, some of the controlling factors of heavy metals distribution are also discussed. The average heavy metals contents decrease in the order of $\mathrm{Zn}>\mathrm{Cr}>\mathrm{Pb}>\mathrm{Cu}>\mathrm{As}>\mathrm{Cd}$. The averaged pollution degree, as shown by the index of geo-accumulation $\left(I_{\text {geo }}\right)$, decreases in the order of $\mathrm{Zn}>\mathrm{Cu}>\mathrm{Pb}>\mathrm{Cr}>\mathrm{Cd}>$ As. Due to the barrier of islands, the $I_{g e o}$ values of $\mathrm{Zn}, \mathrm{Pb}, \mathrm{Cr}, \mathrm{Cu}$, and $\mathrm{Cd}$ near the Hailing and Xiachuan Islands are larger than those in other areas. Meanwhile, the $I_{\text {geo }}$ value of As near the coastal area off the estuary of Wanquan River is clearly larger than that in other areas. Based on the results of potential ecological risk index, $\mathrm{Cd}, \mathrm{Cu}$, and As should be paid more attention for the contamination risk in future. The results of Pearson correlation analysis and principal component analysis indicate that $\mathrm{Zn}, \mathrm{Cr}, \mathrm{Pb}, \mathrm{Cu}$, and $\mathrm{Cd}$ are mainly from the Pearl River and surrounding small rivers, whereas As originates from the Hainan Island. The grain size is one of the main controlling factors for heavy metals distribution, and the anthropogenic activity also plays an important role.
\end{abstract}

Keywords: surface sediments; heavy metals; South China Sea; pollution degree; potential ecological risk; sources identification

\section{Introduction}

Over the past century, because of the rapid industrialization, estuaries and coastal areas have become the main sinks of the anthropogenic pollutants, which mainly consist of industrial and domestic sewage discharges, smelting, mining, and $e$-wastes recycling. Toxic contaminants such as persistent organic pollutants and metals bring increasing pressure to the coastal and estuarine ecosystems over the past decades due to the enhanced human activities [1]. Metals are naturally occurring constituents in the environment and vary in concentrations in different areas. Unlike organic pollutants, metals are considered as non-degradable pollutants, especially for the heavy metals. After deposition, the chemical and biological processes may allow heavy metals to be desorbed from surface sediments upon which they are released into the water column [2]. Therefore, marine sediments serve as both sinks and potential secondary sources of heavy metals [3]. The research on heavy metals in surface sediments provides significant insights into the metal pollution in aquatic systems. In recent years, 
numerous efforts have been made to investigate the influences of heavy metals in the coastal area [4-9]. All results show the influences of terrigenous input for the heavy metal pollution.

The continental shelf in the northern South China Sea is relatively flat and wide, and receives a large amount of materials from the Pearl River and the surrounding land, which is one of the most developed regions in China. The multiple sources and hydrodynamic conditions make it play an important role in discussing the sources, transportation and deposition of heavy metals in the South China Sea. However, the comprehensive understanding of heavy metals provenance and their potential threats for the marine ecosystem in this area is limited.

The main objectives of the present study are to (1) characterize the spatial distribution of heavy metals in surface sediments, (2) identify the sources of heavy metals and controlling factors of the heavy metals distribution, and (3) assess the heavy metals pollution degree and their potential ecological risk index (PERI).

\section{Materials and Methods}

\subsection{Study Area}

The study area is located on the northern South China Sea continental shelf, off the western Guangdong Province and northeastern Hainan Island (Figure 1). Annual sediment fluxes in this area include approximately $84 \mathrm{Mt}$ from Pearl River and $4 \mathrm{Mt}$ from other small rivers (e.g., Jian River, Moyang River, Nandu River, and Wanquan River) [10]. The general surface circulation in the study area is largely seasonal and is driven primarily by the distinct seasonal monsoon winds [11,12]. In winter, the Guangdong coastal current flows along the northeasterly direction of the winter monsoon winds. In summer, the South China Sea warm current becomes prevailing southeasterly surface current forced apparently by the summer monsoon winds [13] (Figure 1).

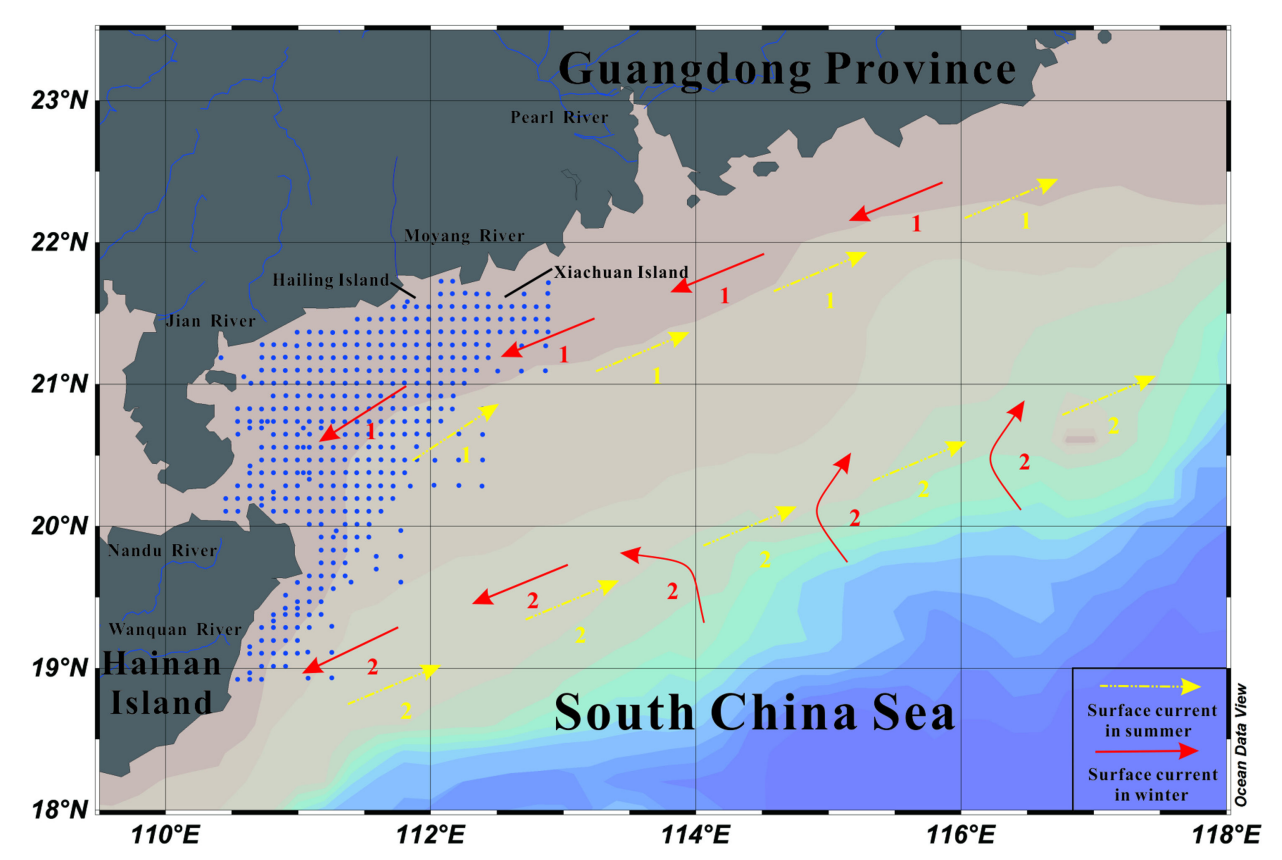

Figure 1. Map of the study area showing the locations of surface sediment samples. Seasonal variations of surface circulation patterns on the northern South China Sea continental shelf (revised from reference [13]). 1. Chinese Coastal Current; 2. South China Sea warm current.

\subsection{Sample Collection and Analytical Methods}

A total of 388 surface sediment samples were collected by the Second Institute of Oceanography, State Oceanic Administration and South China Sea Branch, State Oceanic Administration in 2008 
(samples location see Figure 1). The heavy metals contents of $\mathrm{Cd}, \mathrm{Cr}, \mathrm{Cu}, \mathrm{Pb}, \mathrm{Zn}$, and As were identified using an Inductively Coupled Plasma Mass Spectrometer (ICP-MS) (iCAP Qc, Thermo Fisher Scientific, Waltham, MA, USA) at the Institute of Geophysical and Geochemical Exploration, Chinese Academy of Geological Sciences, China. Prior to chemical analysis, the samples were dried below $105^{\circ} \mathrm{C}$, crushed to $<200$ mesh size in an agate mortar, and stored in clean polyethylene bags at room temperature. For acid digestion, precisely $0.25 \mathrm{~g}$ of each sample was put in a Teflon bomb with an acid mixture (5:4:1 $\left.\mathrm{V}\left(\mathrm{HNO}_{3}\right)+\mathrm{V}(\mathrm{HCl})+\mathrm{V}(\mathrm{HF})\right)[14]$ and then heated to $120^{\circ} \mathrm{C}$ for $12 \mathrm{~h}$ on a heating plate. The acid digestion was repeated until only a negligible amount of white residue remained. Then, the solution was evaporated to dry and extracted with $\mathrm{HNO}_{3}$. There were 22 certified reference materials and 23 duplicate samples analyzed for the data quality control. Most of the mean relative standard deviations for duplicate samples are less than $7.00 \%$, except for Cd (10.62\%).

\subsection{Assessment Methods}

\subsubsection{Index of Geo-Accumulation ( $\left.I_{\text {geo }}\right)$}

The $I_{g e o}$ was firstly introduced by Müller [15]. It is a quantitative index to study heavy metal contamination in aquatic sediments and has been widely used to evaluate the contamination degree of heavy metals in surface sediments. The formula was as follows:

$$
I_{\text {geo }}=\log _{2}\left(\frac{C^{i}}{1.5 \times C_{n}^{i}}\right)
$$

where $C^{i}$ is the mean content of the heavy metal $i$ in the surface sediments; $C_{n}^{i}$ is the baseline content of $i$. The factor 1.5 is used due to possible variations in background values for the metal in the environment [16]. The baseline values $\left(C_{n}^{i}\right)$ of $\mathrm{Cu}, \mathrm{Pb}, \mathrm{Zn}, \mathrm{Cr}, \mathrm{Cd}$, and As around the study area are $14.2 \mu \mathrm{g} / \mathrm{g}, 28.8 \mu \mathrm{g} / \mathrm{g}, 59 \mu \mathrm{g} / \mathrm{g}, 56 \mu \mathrm{g} / \mathrm{g}, 0.08 \mu \mathrm{g} / \mathrm{g}$, and $13.5 \mu \mathrm{g} / \mathrm{g}$, respectively, which are obtained through analyzing the soils from Guangdong Province [17]. The $I_{g e o}$ values are grouped into classes to represent different pollution levels, the definitions [18] for which are listed in Table 1.

Table 1. Classification of Index of geo-accumulation $\left(I_{g e o}\right)$ [18].

\begin{tabular}{ccc}
\hline $\boldsymbol{I}_{\text {geo }}$ & Class & Pollution Level \\
\hline$<0$ & 0 & Unpolluted \\
$0-1$ & 1 & Unpolluted to moderately polluted \\
$1-2$ & 2 & Moderately polluted \\
$2-3$ & 3 & Moderately to strongly polluted \\
$3-4$ & 4 & Strongly polluted \\
$4-5$ & 5 & Strongly to very strongly polluted \\
$>5$ & 6 & Very strongly polluted \\
\hline
\end{tabular}

\subsubsection{PERI}

The $I_{g e o}$ can only reflect the influence of human activities on the enrichment of single heavy metal and do not consider the bioavailability, hydrodynamic condition or combined effects of heavy metals [19]. Therefore, the PERI was a quantitative index that evaluated the pollution and potential risks associated with the accumulation of one or more heavy metals [20,21]. The formulas of PERI were as follows:

$$
\begin{gathered}
C_{d g}=\sum_{i=1}^{k} C_{f}^{i}=\sum_{i=1}^{k} \frac{C^{i}}{C_{n}^{i}} \\
\mathrm{RI}=\sum_{i=1}^{k} E_{n}^{i}=\sum_{i=1}^{k} \frac{T_{n}^{i} \cdot C^{i}}{C_{n}^{i}}
\end{gathered}
$$


where $C^{i}$ is the mean content of the heavy metal $i$ in the surface sediments; $C_{n}^{i}$ is the baseline content of $i ; C_{f}^{i}$ is the contamination factor of $i ; C_{d g}$ is the degree of contamination; $T_{n}^{i}$ is the toxic-response factor for $i$; $E_{n}^{i}$ is the potential ecological risk factor for $i$; RI is the PERI; and $k$ is the species of the heavy metals. In this study, we use $\mathrm{Cu}, \mathrm{Pb}, \mathrm{Zn}, \mathrm{Cr}, \mathrm{Cd}$, and As to evaluate the PERI. And the toxic-response factors $\left(T_{n}^{i}\right)$ for these six elements are 5, 5, 1,2,30, and 10, respectively [20], the baseline values $\left(C_{n}^{i}\right)$ are showed above. The categories [20] of pollution and PERI for sediments are listed in Table 2.

Table 2. Classification of pollution degree and potential ecological risk for surface sediments [20].

\begin{tabular}{|c|c|c|c|}
\hline$C_{d g}$ & $\begin{array}{c}\text { Degree of } \\
\text { Contamination }\end{array}$ & RI & $\begin{array}{c}\text { Grade of Potential Ecological Risk } \\
\text { to the Environment }\end{array}$ \\
\hline$<6$ & low pollution & $<150$ & low potential risk \\
\hline $6-12$ & moderate pollution & $150-300$ & moderate potential risk \\
\hline $12-24$ & high pollution & $300-600$ & high potential risk \\
\hline$\geq 24$ & severe pollution & $\geq 600$ & severe potential risk \\
\hline
\end{tabular}

\subsection{Statistical Methods}

Multiple statistical analyses have been widely used to distinguish sources and controlling factors in heavy metal contamination assessments $[3,6,22,23]$. The Pearson correlation coefficients and principal component analysis among the various types of heavy metals were calculated and displayed in Tables 3 and 4. In addition, the grain size data of the surface sediments from the study area have been published by Chu et al. [24] in 2010, we cite the mean grain size (Mz) data to compare with the contents of heavy metals in the statistical analyses. To maximize the sum of variances of squared loadings, a varimax rotation was used when calculating the principal components. The principal component analysis can reduce the dimensionality of geochemical data. Meanwhile, this method has been proven to be an effective tool that can be used to identify potential sources and controlling factors of heavy metals distribution and has been widely used in combination with correlation analysis [3,25].

Table 3. Pearson correlation matrix of heavy metals contents and mean grain size [24].

\begin{tabular}{|c|c|c|c|c|c|c|c|}
\hline & As & $\mathrm{Cd}$ & $\mathrm{Cr}$ & $\mathrm{Cu}$ & $\mathrm{Pb}$ & $\mathrm{Zn}$ & $\mathbf{M z}$ \\
\hline As & 1 & & & & & & \\
\hline $\mathrm{Cd}$ & $0.594^{* *}$ & 1 & & & & & \\
\hline $\mathrm{Cr}$ & $0.347^{* *}$ & $0.651^{* *}$ & 1 & & & & \\
\hline $\mathrm{Cu}$ & $0.599 * *$ & $0.894^{* *}$ & $0.763^{* *}$ & 1 & & & \\
\hline $\mathrm{Pb}$ & $0.626^{* *}$ & $0.828 * *$ & $0.816^{* *}$ & $0.915^{* *}$ & 1 & & \\
\hline $\mathrm{Zn}$ & $0.492 * *$ & $0.829^{* *}$ & $0.911^{* *}$ & $0.924^{* *}$ & $0.931^{* *}$ & 1 & \\
\hline $\mathrm{Mz}$ & $0.168^{* *}$ & $0.571^{* *}$ & $0.845^{* *}$ & $0.630^{* *}$ & $0.688^{* *}$ & $0.790^{* *}$ & 1 \\
\hline
\end{tabular}

Table 4. General characteristics of the heavy metals contents in surface sediments from the study area.

\begin{tabular}{ccccccc}
\hline Parameter & $\mathbf{C d}$ & $\mathbf{C r}$ & $\mathbf{C u}$ & $\mathbf{P b}$ & $\mathbf{Z n}$ & $\mathbf{A s}$ \\
\hline Maximum $(\mu \mathrm{g} / \mathrm{g})$ & 0.40 & 93.50 & 111.80 & 78.10 & 251.90 & 50.55 \\
Minimum $(\mu \mathrm{g} / \mathrm{g})$ & 0.02 & 8.20 & 2.10 & 8.90 & 8.00 & 0.37 \\
Average $(\mu \mathrm{g} / \mathrm{g})$ & 0.08 & 56.71 & 17.72 & 28.71 & 74.22 & 9.14 \\
Coefficient of variance $(\%)$ & 51.86 & 35.53 & 64.88 & 36.73 & 45.41 & 52.67 \\
\hline
\end{tabular}

\section{Results and Discussion}

\subsection{Contents and Spatial Distribution of Heavy Metals in the Surface Sediments}

Table 4 summarizes the basic statistics of heavy metals in surface sediments from the continental shelf off the western Guangdong Province and northeastern Hainan Island. The average contents of 
these elements decreased in the order of $\mathrm{Zn}(74.22 \mu \mathrm{g} / \mathrm{g})>\mathrm{Cr}(56.71 \mu \mathrm{g} / \mathrm{g})>\mathrm{Pb}(28.71 \mu \mathrm{g} / \mathrm{g})>\mathrm{Cu}$ $(17.72 \mu \mathrm{g} / \mathrm{g})>\mathrm{As}(9.14 \mu \mathrm{g} / \mathrm{g})>\mathrm{Cd}(0.08 \mu \mathrm{g} / \mathrm{g})$. The maximum values of $\mathrm{Cd}, \mathrm{Cu}$, and As exceed the secondary standard of Environmental quality standard for soils (GB 15618-1995) in China, and those of $\mathrm{Cr}, \mathrm{Pb}$, and $\mathrm{Zn}$ exceed the first standard (natural background). Based on the coefficient of variance, the contents of heavy metals varied distinctly among sampling sites, especially for $\mathrm{Cu}, \mathrm{As}$, and $\mathrm{Cd}$, with the values of $64.88 \%, 52.67 \%$, and $51.86 \%$, respectively (Table 4 ). The coefficient of variance can reflect the transport ability for heavy metals with similar origins [7]. The higher coefficient of variance is associated with weaker transport regime. Therefore, the delivery of $\mathrm{Cu}$ is weakest while that of $\mathrm{Cr}$ is the strongest.

Ge et al. [26], based on geophysical data indicated that the Pearl River-derived fine sediments were mostly deposited in the water depth shallower than $\sim 50 \mathrm{~m}$ on the continental shelf off the western Guangdong Province. As shown in Figure 2, the heavy metals exhibit various distribution patterns in the study area. For example, the content of $\mathrm{Zn}$ is rich in the water shallower than $\sim 50 \mathrm{~m}$, and then decreases to lower than $70 \mu \mathrm{g} / \mathrm{g}$ in deeper water. This spatial distribution pattern corresponds to those of silt and clay contents in the study area [24], which indicates that fine sediment is enriched of $\mathrm{Zn}$. The distribution patterns of $\mathrm{Pb}$, and $\mathrm{Cr}$ are similar to that of $\mathrm{Zn}$, although their extensions are different. The distribution pattern of As shows slight variations in the study area, except for the shelf off the eastern Hainan Island. Meanwhile, the distribution patterns of $\mathrm{Cu}$ and $\mathrm{Cd}$ display the highest values in the coastal area off the Guangdong Province, around the Hailing, Xiachuan Islands (Figure 2).

\subsection{Pollution Assessment}

Heavy metals in marine sediments originate from various sources, primarily including the weathering of rocks, discharge of upstream wastewater and atmospheric input. Among these sources, wastewater is the dominant one in the coastal area [7]. Heavy metals are primarily transported to the ocean with terrigenous materials in either adsorbed or dissolved phase [27]. After delivered to the ocean, heavy metals can rapidly convert from the aqueous phase to the solid phase and ultimately accumulate in seafloor deposits [28]. Such accumulation can affect the environment and contaminate the marine food chain. Therefore, evaluating the harm of heavy metals' pollution is critically important.

The $I_{\text {geo }}$ values of heavy metals range from -2.89 to 1.72 with a mean value of -0.74 for $\mathrm{Cd},-3.35$ to 0.15 with a mean value of -0.71 for $\mathrm{Cr},-3.34$ to 2.39 with a mean value of -0.58 for $\mathrm{Cu},-2.28$ to 0.86 with a mean value of -0.69 for $\mathrm{Pb},-3.47$ to 1.51 with a mean value of -0.46 for $\mathrm{Zn}$, and -5.78 to 1.32 with a mean value of -1.31 for As, respectively (Figure 3). The mean pollution degrees of these heavy metals can be ranked in the decreasing order of $\mathrm{Zn}>\mathrm{Cu}>\mathrm{Pb}>\mathrm{Cr}>\mathrm{Cd}>$ As. According to the classification of Fostner and Müller [18], the $I_{g e o}$ values of $\mathrm{Cr}$ and $\mathrm{Pb}$ suggested no pollution or minor to moderate pollution (Figure 3, Table 1). However, the $I_{g e o}$ values of $\mathrm{Cd}, \mathrm{Cu}, \mathrm{Zn}$, and As implied heavier degrees of pollution (Figure 3). As shown in Figure 3, the $I_{\text {geo }}$ values of $\mathrm{Zn}, \mathrm{Pb}, \mathrm{Cr}, \mathrm{Cu}$, and $\mathrm{Cd}$ near the Hailing and Xiachuan Islands were larger than those in other areas, which could be attributed to the increasing of flocculation. Due to the block of these islands, the flow shear stress decreased, and the fluvial materials with heavy metals occurred flocculation effect to deposit easily. Meanwhile, the $I_{g e o}$ value of As near the coastal area off estuary of Wanquan River was clearly larger than that in other areas (Figure 3). 

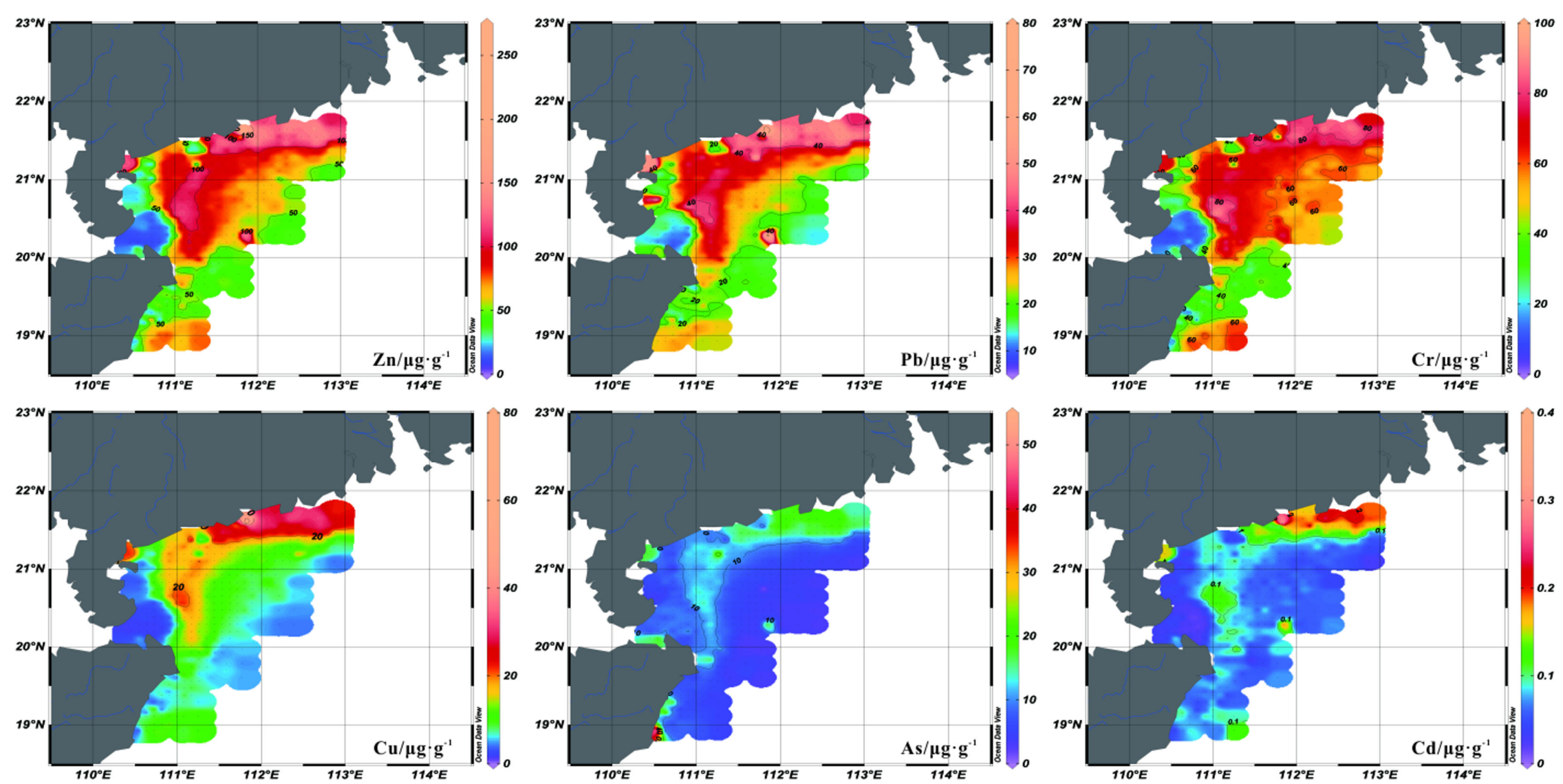

Figure 2. Spatial distribution patterns of the contents for heavy metals in the study area. 

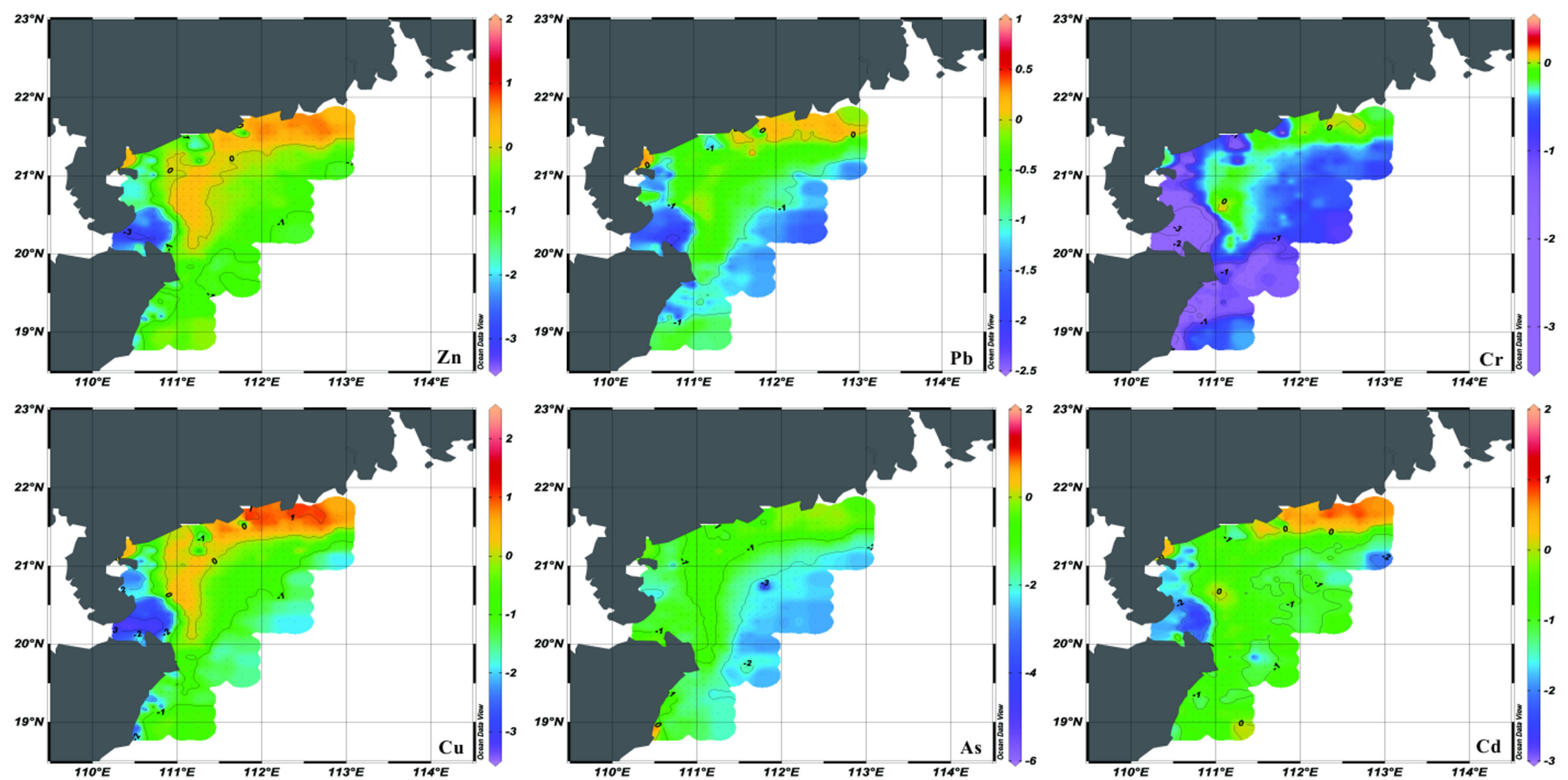

Figure 3. Spatial distribution pattern of index of geo-accumulation $\left(I_{g e e}\right)$ for heavy metals in the study area. 
Potential ecological risk related to heavy metals in surface sediments from the study area was calculated based on Equations (2) and (3). From Equation (2), the mean values of $C_{f}^{i}$ for $\mathrm{Cu}, \mathrm{Pb}, \mathrm{Zn}$, $\mathrm{Cr}, \mathrm{Cd}$, and As are 1.25, 1.00, 1.26, 1.01, 1.00, and 0.68, respectively. The pollution degree caused by these elements can be ranked as follows: $\mathrm{Zn}>\mathrm{Cu}>\mathrm{Cr}>\mathrm{Pb}=\mathrm{Cd}>\mathrm{As}$. The mean value of $C_{d g}$ is 6.20 , and the maximum value is 21.90 . This implies that the pollution degree of these elements is low to high in most of the study area (Figure 4). Meanwhile, Figure 4 also shows that highly polluted regions are primarily located in the coastal area off the Guangdong Province, around the Hailing, Xiachuan Islands, and Zhanjiang City. From Equation (3), the mean values of $E_{n}^{i}$ for $\mathrm{Cu}, \mathrm{Pb}, \mathrm{Zn}, \mathrm{Cr}$, $\mathrm{Cd}$, and As are 6.24, 4.98, 1.26, 2.03, 30.19, and 6.77, respectively. The potential ecological risk of these elements can be ranked as follows: $\mathrm{Cd}>\mathrm{Cu}>\mathrm{As}>\mathrm{Pb}>\mathrm{Cr}>\mathrm{Zn}$. The average value of $\mathrm{RI}$ is 51.47, and its maximum is 216.93. This implies that the potential ecological risks of these elements are low to moderate. Based on the comparison of these parameters, the rankings of potential ecological risk changed, with $\mathrm{Cd}$ and As rising and $\mathrm{Zn}$ falling. This shift indicates that $\mathrm{Cd}$ and As impose more potential ecological risks on the study area. The Figure 4 shows that moderate potential risk region is also found in the coastal area off the Guangdong Province and Hainan Island, especially for waters around Hailing and Xiachuan Islands.
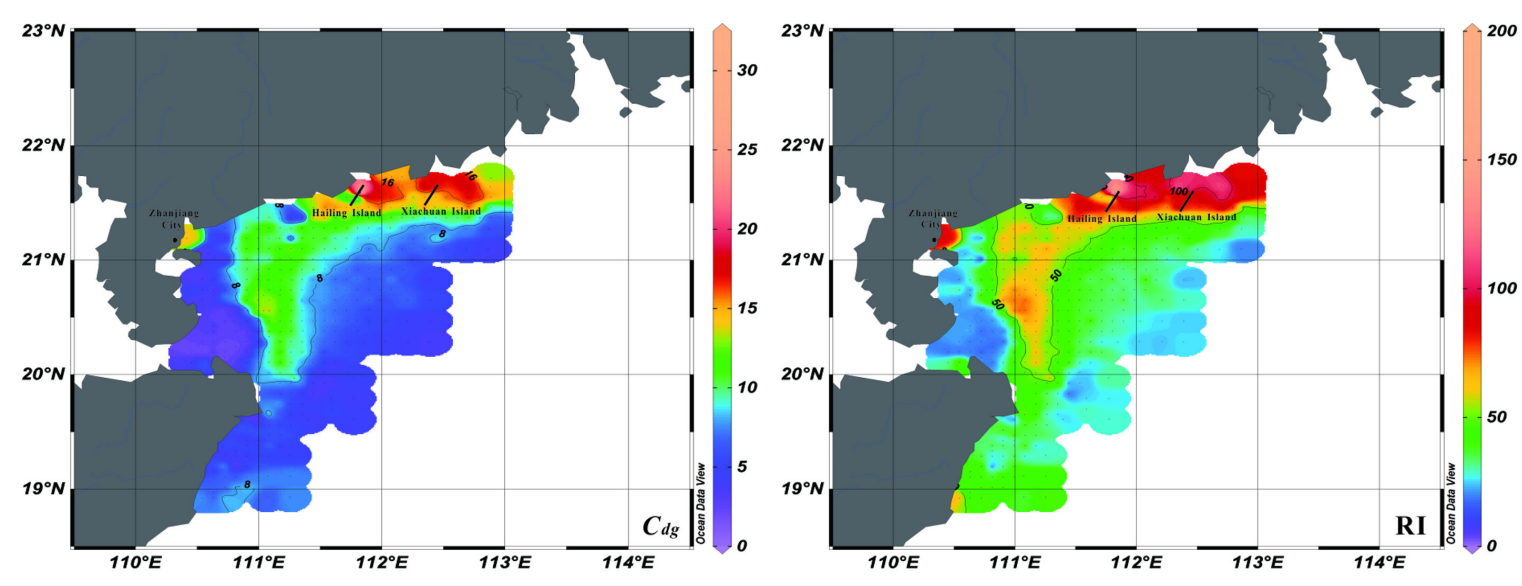

Figure 4. Spatial distribution patterns of the degree of contamination $\left(C_{d g}\right)$ and potential ecological risk index (RI) for heavy metals in the study area.

\subsection{Controlling Factors of Heavy Metals Distribution and Sources Identification}

The Pearson correlation coefficients among the contents of heavy metals and Mz are shown in Table 3. The result showed that the heavy metals were significantly and positively correlated with each other except As. Content of As was not significantly correlated with any other heavy metals and $\mathrm{Mz}$. Significant correlations were found between several elemental pairs: $\mathrm{Cu}-\mathrm{Cd}(0.894), \mathrm{Pb}-\mathrm{Cd}(0.828)$, $\mathrm{Zn}-\mathrm{Cd}$ (0.829), Cu-Cr (0.763), $\mathrm{Pb}-\mathrm{Cr}$ (0.816), Zn-Cr (0.911), $\mathrm{Pb}-\mathrm{Cu}(0.915), \mathrm{Zn}-\mathrm{Cu}(0.924)$, and Zn-Pb (0.931). Therefore, $\mathrm{Cd}, \mathrm{Cr}, \mathrm{Cu}, \mathrm{Pb}$, and $\mathrm{Zn}$ were positively correlated among each other and might have the similar sources.

The results of principal component analysis were shown in Table 5. The top two principal components explained $90.2 \%$ of the total variances. For factor loadings, F1 (53.5\% of variance) shows high positive loadings of $\mathrm{Cr}, \mathrm{Pb}$, and $\mathrm{Zn}$, and a moderate positive loading of $\mathrm{Cu}$, and $\mathrm{F} 2$ (36.7\% of variance) displays high positive loadings of $\mathrm{As}, \mathrm{Cd}$, and a moderate positive loading of $\mathrm{Cu}$. Based on the combination patterns, these two principal components should represent different controlling factors. 
Table 5. Rotated component matrix for principal component analysis loadings for heavy metals contents and mean grain size [24] in the surface sediment from the study area.

\begin{tabular}{ccc}
\hline Component & F1 & F2 \\
\hline $\mathrm{Cd}$ & 0.580 & $\mathbf{0 . 7 0 1}$ \\
$\mathrm{Cr}$ & $\mathbf{0 . 9 1 2}$ & 0.268 \\
$\mathrm{Cu}$ & $\mathbf{0 . 6 7 7}$ & $\mathbf{0 . 6 7 8}$ \\
$\mathrm{Pb}$ & $\mathbf{0 . 7 1 6}$ & 0.645 \\
$\mathrm{Zn}$ & $\mathbf{0 . 8 4 8}$ & 0.499 \\
$\mathrm{As}$ & 0.045 & $\mathbf{0 . 9 3 8}$ \\
$\mathrm{Mz}$ & $\mathbf{0 . 9 4 2}$ & 0.053 \\
Variance \% & 53.5 & 36.7 \\
Cumulative variance \% & 53.5 & 90.2 \\
\hline
\end{tabular}

Bold fonts represent the high positive loadings in principal component analysis.

F1 represents the high positive loadings for Mz (Table 5). And the distribution patterns of silt and clay contents [24] are corresponding to those of $\mathrm{Cr}, \mathrm{Pb}, \mathrm{Zn}$, and $\mathrm{Cu}$ (Figure 2), which means these heavy metals enrich in the fine sediments. Above evidence indicate that grain size is the most important factor controlling the distribution patterns of these heavy metals in the study area. Actually, the hydrodynamic environment could influence the characteristic of grain size [29]. As shown in Figure 3, the mean pollution degrees of these heavy metals are mostly moderate, especially for the nearshore area. And the distribution patterns of these heavy metals show agreements with that of Pearl River-derived fine sediment [26], indicating the possibility of Pearl River source. To further validate this transport pattern, we refer to the suspended sediment concentration (SSC) in winter simulated by the numerical model (Figure 5). This model adopts the Regional Ocean Modelling System (ROMS), which is a free-surface, finite difference circulation model, and is formulated in a vertical terrain following sigma coordinate [30]. Model simulated fine sediments confirmed the transport pattern revealed by the heavy metal data in this study. Yang et al. [31] proposed that the fluvial sediments in the Yellow and East China Seas were firstly deposited on the continental shelf near the estuary, and then re-suspended and transported by the southwestward Chinese coastal current when East Asian winter monsoon prevails. This sediment transportation pattern of "summer deposit and winter transport" is also proved in the northern South China Sea [26]. The Pearl River-derived fine sediment carried with $\mathrm{Cr}, \mathrm{Pb}, \mathrm{Zn}$, and $\mathrm{Cu}$ transported into the ocean, and deposited on the shelf near the estuary firstly in summer. When winter monsoon prevails, these sediments were re-suspended and transported by the southwestward Chinese Coastal Current toward the Leizhou Peninsula. The high SSC area locates in the water shallower than $\sim 50 \mathrm{~m}$ (Figure 5). The sediment transport mechanism can explain the spatial distribution of $\mathrm{Cr}, \mathrm{Pb}, \mathrm{Zn}$, and $\mathrm{Cu}$, which decreased from north to south and west progressively. Meanwhile, the anomalously high contents and $I_{g e o}$ around the Hailing and Xiachuan Islands could be explained by the blocking of the Pearl River-derived sediments (Figures 2 and 3).

Another important factor affecting the spatial distribution of heavy metals is anthropogenic activity. F2 displays high positive loadings of $\mathrm{As}, \mathrm{Cd}$, and a moderate positive loading of $\mathrm{Cu}$. The top three heavy metals of high potential ecological risk are $\mathrm{Cd}, \mathrm{Cu}$, and As, which shows the influence of anthropogenic activity. The distribution pattern of As was different from that of other heavy metals, with higher contents on the shelf off the eastern Hainan Island (Figure 2). Meanwhile, the distribution pattern of RI also showed a high value region in this area, which was different to that of $C_{d g}$. The rankings of potential ecological risk showed the rising threat of As. This area was mainly influenced by the local rivers from eastern Hainan Island, such as Wanquan River. Although the pollution degree in this area is low right now, the potential ecological risk is rising due to the rapid developing of nearby cities, such as Town of Boao (Figure 4). Through analyzing the distribution patterns of $\mathrm{Cu}$ and $\mathrm{Cd}$ (Figure 2), we consider that the main sources of these heavy metals are rivers from Guangdong Province. The Pearl River flows through Guangdong Province, which is one of the most developed regions in China. The rapid economic development brings lots of 
pollutions, especially for $\mathrm{Cu}$ and $\mathrm{Cd}$. In addition to the Pearl River, other sources might come from the mining and electroplating industry along some local rivers, such as Moyang River [32]. In conclusion, the anthropogenic activity makes the potential ecological risks of $\mathrm{As}, \mathrm{Cd}$, and $\mathrm{Cu}$ rising, and the weak delivery capacity of these heavy metals may aggravate the pollution.

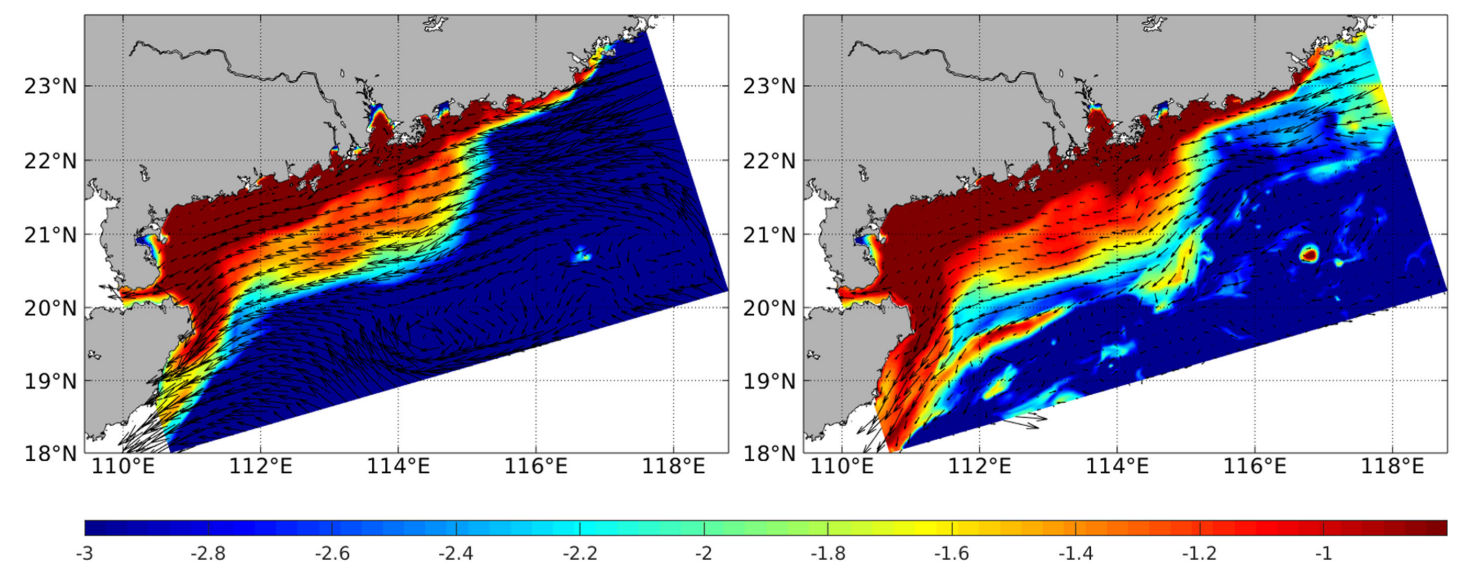

Figure 5. Simulated Suspended Sediment Concertation (SSC) in December 2016 (color shading scaled in $\log 10$, unit: $\mathrm{g} / \mathrm{L}$ ) and currents at surface (left) and bottom (right), respectively.

\section{Conclusions}

We analyzed the spatial distribution patterns, $I_{g e o}$, PERI, controlling factors, and sources of heavy metals including $\mathrm{Cd}, \mathrm{Cr}, \mathrm{Cu}, \mathrm{Pb}, \mathrm{Zn}$, and $\mathrm{As}$ in the surface sediments from the continental shelf off the western Guangdong Province and northeastern Hainan Island. The average contents of $\mathrm{Zn}, \mathrm{Cr}, \mathrm{Pb}, \mathrm{Cu}$, As, and $\mathrm{Cd}$ were 74.22, 56.71, 28.71, 17.72, 9.14, and $0.08 \mu \mathrm{g} / \mathrm{g}$, respectively. Meanwhile, $\mathrm{Zn}, \mathrm{Cr}, \mathrm{Pb}$, and $\mathrm{Cu}$ exhibited similar spatial distribution patterns decreasing from north to south and west toward the Qiongzhou Strait, which corresponded to the pathway of the Pearl River-derived fine sediments. Based on the results of $I_{g e o}$ and PERI, Cd, Cu, Zn, and As were identified as the major heavy metal pollutants in surface sediments. The potential ecological risks of heavy metals are low to moderate. The results of statistical analyses showed that $\mathrm{Zn}, \mathrm{Cr}, \mathrm{Pb}, \mathrm{Cu}$, and $\mathrm{Cd}$ were mainly from the Pearl River and surrounding small rivers, whereas As originated from the Hainan Island. The factors controlling heavy metals characteristics were analyzed and indicated that grain size is one of the main factors. In addition, the anthropogenic activity can also influence the distribution patterns of heavy metals.

Author Contributions: All authors contributed to the data assessment and analysis strategy. Q.G. coordinated and wrote the main text with contributions from the other co-authors. Q.G. and F.C. provided the funding support, and Z.G.X. reviewed and edited the manuscript.

Acknowledgments: This work was supported by the National Programme on Global Change and Air-Sea Interaction (Grant Nos. GASI-GEOGE-03 and GASI-GEOGE-06-02), and the National Natural Science Foundation of China (Grant Nos. 41476047, 41106045, 41506064 and 41427803). We would like to acknowledge the Institute of Geophysical and Geochemical Exploration, Chinese Academy of Geological Sciences, China for the technical assistance in laboratory analysis. We gratefully thank Zhigang Yao from the Ocean University of China, and Yanhui Dong from the Second Institute of Oceanography, State Oceanic Administration, for the assistance in the modelling and data analysis, respectively.

Conflicts of Interest: The authors declare no conflict of interest.

\section{References}

1. Pan, K.; Wang, W.X. Trace metal contamination in estuarine and coastal environments in China. Sci. Total Environ. 2012, 421-422, 3-16. [CrossRef] [PubMed]

2. Tessier, A.; Campbell, P.G.C. Partitioning of trace metals in sediments: Relationships with bioavailability. Hydrobiologia 1987, 149, 43-52. [CrossRef] 
3. Wang, Y.Q.; Yang, L.Y.; Kong, L.H.; Liu, E.; Wang, L.; Zhu, J. Spatial distribution, ecological risk assessment and source identification for heavy metals in surface sediments from Dongping Lake, Shandong, East China. Catena 2015, 125, 200-205. [CrossRef]

4. Ip, C.C.M.; Li, X.D.; Zhang, G.; Wai, O.W.; Li, Y.S. Trace metal distribution in sediments of the Pearl River Estuary and the surrounding coastal area, South China. Environ. Pollut. 2007, 147, 311-323. [CrossRef] [PubMed]

5. Hernandez, O.C.; Hoz, L.R.; Cundy, A.B.; Carranza-Edwards, A. Sedimentary heavy metal(loid) contamination in the Veracruz shelf, Gulf of Mexico: A baseline survey from a rapidly developing tropical coast. Mar. Pollut. Bull. 2017, 119, 204-213. [CrossRef] [PubMed]

6. Lu, J.; Li, A.C.; Huang, P. Distribution, sources and contamination assessment of heavy metals in surface sediments of the South Yellow Sea and northern part of the East China Sea. Mar. Pollut. Bull. 2017, 124, 470-479. [CrossRef] [PubMed]

7. Zhang, Z.Q.; Chen, L.; Wang, W.P.; Li, T.; Zu, T. The origin, historical variations, and distribution of heavy metals in the Qiongzhou Strait and nearby marine areas. J. Ocean Univ. China 2017, 16, 262-268. [CrossRef]

8. Chen, F.J.; Lin, J.; Qian, B.H.; Wu, Z.; Huang, P.; Chen, K.; Li, T.; Cai, M. Geochemical assessment and spatial analysis of heavy metals in the surface sediments in the eastern Beibu Gulf: A reflection on the industrial development of the South China coast. Int. J. Environ. Res. Public Health 2018, 15, 496. [CrossRef] [PubMed]

9. Liu, J.J.; Ni, Z.X.; Diao, Z.H.; Hu, Y.X.; Xu, X.R. Contamination level, chemical fraction and ecological risk of heavy metals in sediments from Daya Bay, South China Sea. Mar. Pollut. Bull. 2018, 128, 132-139. [CrossRef] [PubMed]

10. Milliman, J.D.; Farnsworth, K.L. River Discharge to the Coastal Ocean: A Global Synthesis; Cambridge University Press: Cambridge, UK, 2011; pp. 1-384.

11. Shaw, P.-T.; Chao, S.-Y. Surface circulation in the South China Sea. Deep Sea Res. Part I 1994, 41, $1663-1683$. [CrossRef]

12. Su, J.L. Overview of the South China Sea circulation and its influence on the coastal physical oceanography near the Pearl River Estuary. Cont. Shelf Res. 2004, 24, 1745-1760.

13. Liu, Z.F.; Colin, C.; Li, X.J.; Zhao, Y.; Tuo, S.; Chen, Z.; Siringan, F.P.; Liu, J.T.; Huang, C.-Y.; You, C.-F.; et al. Clay mineral distribution in surface sediments of the northeastern South China Sea and surrounding fluvial drainage basins: Source and transport. Mar. Geol. 2010, 277, 48-60. [CrossRef]

14. Loring, D.H.; Rantala, R.T.T. Manual for the geochemical analyses of marine sediments and suspended particulate matter. Earth-Sci. Rev. 1992, 32, 235-283. [CrossRef]

15. Müller, G. Index of geoaccumulation in sdiments of the Rhine River. Geojournal 1969, 2, 108-118.

16. Müller, G. Schwermetalle in den Sedimenten des Rheins-Veränderungen seit 1971. Umschau 1979, 79, 778-783.

17. Li, J.; Zheng, C.J. Handbook of Environmental Background Values; China Environmental Science Press: Beijing, China, 1988; pp. 1-403. (In Chinese)

18. Fostner, U.; Müller, G. Concentration of trace metals and polycyclic aromatic hycarbons in river sediments: Geochemical background, man's influence and environmental impact. Geojournal 1981, 5, 417-432. [CrossRef]

19. Dung, T.T.T.; Cappuyns, V.; Swennen, R.; Phung, N.K. From geochemical background determination to pollution assessment of heavy metals in sediments and soils. Rev. Environ. Sci. Biotechnol. 2013, 12, 335-353. [CrossRef]

20. Hakanson, L. An ecological risk index for aquatic pollution control: A sedimentological approach. Water Res. 1980, 14, 975-1001. [CrossRef]

21. Kwon, Y.T.; Lee, C.W. Application of multiple ecological risk indexes for the evaluation of heavy metal contamination in a coastal dredging area. Sci. Total Environ. 1998, 214, 203-210. [CrossRef]

22. Selvaraj, K.; Ram Mohan, V.; Szefer, P. Evaluation of metal contamination in coastal sediments of the Bay of Bengal, India: Geochemical and statistical approach. Mar. Pollut. Bull. 2004, 49, 174-185. [CrossRef] [PubMed]

23. Mali, M.; Dell'Anna, M.M.; Notarnicola, M.; Damiani, L.; Mastrorilli, P. Combining chemometric tools for assessing hazard sources and factors acting simultaneously in contaminated areas. Case study: "Mar Piccolo" Taranto (South Italy). Chemosphere 2017, 184, 784-794. [CrossRef] [PubMed]

24. Chu, F.Y.; Long, J.P.; Zhang, F.Y.; Zhang, W.Y.; Ye, L.M.; Yang, K.H.; Yang, H.L.; Xu, D.; Ge, Q.; Dong, Y.H.; et al. Report of the Marine Sediment's Characteristic in Zone CJ17; Second Institute of Oceanography, State Oceanic Administration: Hangzhou, China, 2010; pp. 16-47. (In Chinese) 
25. Li, G.; Yan, W.; Li, Z.F. Element geochemistry of offshore sediments in the northwestern South China Sea and the dispersal of Pearl River sediments. Prog. Oceanogr. 2016, 141, 17-29. [CrossRef]

26. Ge, Q.; Liu, J.P.; Xue, Z.; Chu, F. Dispersal of the Zhujiang River (Pearl River) derived sediment in the Holocene. Acta Oceanol. Sin. 2014, 33, 1-9. [CrossRef]

27. Liu, F.W.; Yan, W.; Huang, X.P.; Shi, P. Distributional characteristics of heavy metal and its available phases in sediments from Zhujiang River mouth. J. Trop. Oceanogr. 2003, 22, 16-24. (In Chinese with English abstract).

28. Chen, J.S. Aquatic Chemistry; Higher Education Press: Beijing, China, 1987; pp. 1-302. (In Chinese)

29. Liu, S.F.; Shi, X.F.; Yang, G.; Somkiat, K.; Narumol, K. Concentration distribution and assessment of heavy metals in the surface sediments of the western Gulf of Thailand. Environ. Earth Sci. 2016, 75, 346. [CrossRef]

30. Shchepetkin, A.F.; McWilliams, J.C. The regional oceanic modeling system (ROMS): A split-explicit, free-surface, topography-following-coordinate oceanic model. Ocean Model. 2005, 9, 347-404. [CrossRef]

31. Yang, Z.S.; Guo, Z.G.; Wang, Z.X.; Xu, J.P.; Gao, W.B. The macro pattern of suspended particulate matter transport to the eastern open ocean on the Yellow and East China Sea shelf. Acta Oceanol. Sin. 1992, 14, 81-90. (In Chinese)

32. Chen, L.; Li, T.J.; Yang, W.F.; Chen, J. Distribution and sources of heavy metals in surface sediments, northern South China Sea. Ecol. Environ. Sci. 2016, 25, 464-470. (In Chinese with English abstract).

(c) 2018 by the authors. Licensee MDPI, Basel, Switzerland. This article is an open access article distributed under the terms and conditions of the Creative Commons Attribution (CC BY) license (http:/ / creativecommons.org/licenses/by/4.0/). 